\title{
БЪЛГАРСКА АНТОЛОГИЯ ЗА ПОЛСКАТА ПОЕЗИЯ МЕЖДУ ДВЕТЕ СВЕТОВНИ ВОЙНИ
}

\author{
INA HRISTOVA
}

Uniwersytet Sofijski im. św. Klemensa Ochrydzkiego

\begin{abstract}
A BULGARIAN ANTHOLOGY OF POLISH INTERWAR POETRY. A review of: Karagyozov, Panayot. Polish Poetry Between the Two World Wars. Sofia University Press, 2019, 382 pp. ISBN 978-954-07-4694-4.

Keywords: Panayot Karagyozov, poetic anthology, Polish literature in Bulgaria, literary reception
\end{abstract}

В навечерието на 8о-та годишнина от началото на Втората световна война издателството на Софийския университет Св. Климент Охридски с подкрепата на Полския институт в София отпечата антологията Полската поезия между двете световни войни. Съставителят Панайот Карагьозов, който е автор на предговора и на значителна част от преводите, е включил в книгата стихотворения и поеми от деветнадесет изтъкнати полски поети, както и пет от най-значимите литературни програми и манифести от периода. Подредбата на авторите е извършена на принципите на хронологията и принадлежността им към съответното художествено формирование, а границите между направленията са маркирани чрез фототипните факсимилета на корици на най-популярните през междувоенното двадесетилетие списания.

В пространното въведение Карагьозов разглежда периода в контекста на цялостното развитие на полската литература и съвременната обществено-политическа обстановка, изтъквайки, че след Първата световна война релацията държавно състояние - тип литература отпада и колкото и парадоксално, толкова и закономерно на политико-административното унифициране се противопоставя невиждано по широтата му идейно-естетическо многообразие. Съставителят посочва, че най-лаконичната характеристика на междувоенния плурализъм е метафората на Юлиан Пшибош Въздухът е задушен от знамена! 
Карагьозов припомня, че след като писателите на позитивизма урбанизират прозата, поетите от междувоенното двадесетилетие превръщат града в централен топос на творчеството си. Маркирани са новите тематични кръгове и радикалната промяна в поетическия език, в който навлиза лексика от всекидневието, а поетитефутуристи дори игнорират правилата на синтаксиса, въвеждат множество неологизми и разлагат думата на морфеми. Показано е противопоставянето на миналото от страна на авангардистите и приемствеността в творбите на скамандритите. Посочено е, че поетическите поколения се различават не въз основа на възрастта на авторите, а според отношението им към природата и техниката, а също така и че в поезията младополският символ отстъпва място на междувоенната метафора, която заедно с поантата, освен иманентно-литературните функции, реализира и законите на езиковата икономия.

Според съставителя на антологията феноменална за периода е симбиозата между литературната периодика, литературните кабарета и формалните и неформални писателски формирования. Проследени са възходящото развитие на полската преса от времето на първия полски вестник Merkuriusz Polski и просвещенското списание Monitor до началото на двадесети век; кабаретната традиция, водеща началото си от Млада Полша; литературните програми от времето на спора между К. Броджински и Ян Шнядецки за същността и бъдещето на романтизма; междувоенните манифести. Посочено е, че за пръв път в полската литературна история съревнованието е не само междуличностно, но и между отделните групировки, като лаконично са представени формированията на полските футуристи, на първия и втори авангард и на умерените реформатори около сп. Скамандър.

За пръв път на български са преведени от Кристиян Янев и коментирани от Панайот Карагьозов футуристичните манифести (Манифест на футуристичната поезия от Бруно Яшенски и За делогизирането на поезията от Титус Чижевски), програмните статии на Тадеуш Пайпер в сп. Звротница (Отправна точка и Метафората на съвременността) и Уводните думи на сп. Скамандър. Карагьозов разглежда програмите на Пайпер в единство и смята, че ако към прословутата формула 3-M се прибавят разсъжденията на Пайпер за метафората, формулата може да бъде трансформирана в 4-M (Miasto, Masa, Maszyna, Metafora).

Към най-краткия период в историята на полската литература съставителят причислява и младежите, дебютирали в навечерието и по време на Втората световна война, заключавайки: Мотор на междувоенното двадесетилетие стават поетите от „изгубеното поколение“, надгробната плоча на периода поставят поетите зрелостници от „изтребеното поколение“. 
Наред с вече отпечатвани преводи от Л. Стаф, Б. Лешмян, Й. Либерт, Ю. Тувим, К. Вежински, М. Павликовска-Ясножевска, К. Илаковичувна, Вл. Броневски, Я. Ивашкевич, Ал. Ват и К. И. Галчински, специално за антологията са преведени симптоматични стихове и поеми от Бруно Яшенски, Станислав Млодоженец, Титус Чижевски, Тадеуш Пайпер, Юлиан Пшибош, Юзеф Чехович, Чеслав Милош и Кшищоф Камил Бачински. Особено интересни за българския читател са фигуративните стихове на Т. Чижевски (Химн на машината на моето тяло, Нощ-Ден, Хамлет в мазето), характерните за епохата урбанистични стихотворения на Пайпер (Утро, Улица, Град, С очи над града) и Пшибош (Сгради, Зазидани), както и сравнението на отношението към града в поезията на Т. Пайпер и Христо Смирненски.

Не на последно място заслужава да се отбележи, че преводите са дело на широк поколенчески спектър преводачи, сред които се открояват както имената на класиците Дора Габе, Елисавета Багряна, Димитър Пантелеев, така и на младия полонист Кристиян Янев; също така всеки поет е представен с поне едно стихотворение на оригиналния полски език.

Цялостното представяне на полската междувоенна поезия е значим фрагмент от рецептивния образ на славянските литератури в България. Инициирането и изготвянето на изданието препотвърждава ключовата роля на Панайот Карагьозов за поддържането и постоянното обновяване на българо-полския междулитературен и междукултурен диалог. 